\title{
A Esquerda Verde: Partidos Políticos e Ambientalismo Radical no Brasil
}

\author{
Antonio Teixeira de Barros \\ Centro de Formação da Câmara dos Deputados (CEFOR), Brasília, DF, Brasil. E-mail: \\ antonibarros@gmail.com
}

\section{INTRODUÇÃO}

$\mathrm{O}$ objetivo deste artigo é analisar o perfil e as propostas dos partidos políticos brasileiros que defendem o ambientalismo radical, também conhecido como ecossocialismo (Barros, 2015). O propósito é mapear como as ideias ecossocialistas são articuladas nos programas partidários e que aspectos são enfatizados, além das propostas políticas apresentadas, do perfil de governança ambiental defendido e pela noção de sustentabilidade que orienta os discursos ecossocialistas. $\mathrm{O}$ estudo pretende contribuir para a compreensão do processo político que levou a agenda ambiental a ser apropriada e incorporada pelos partidos de esquerda no Brasil, considerando suas possíveis similaridades e diferenças.

Várias análises contemporâneas enfatizam a crise da mediação política nas sociedades contemporâneas, representada, em boa parte, pela crise dos próprios partidos, especialmente quanto à falta de legitimidade popular e à ênfase em estratégias de manutenção e controle do poder (Panebianco, 1990; Mair, 2008; Braga; Costa; Fernandes, 2018). Outros autores ressaltam a baixa institucionalização partidária no Brasil, a fraca identificação com o eleitorado (Carreirão; Kinzo, 2004; Veiga, 2007) e uma tendência geral na diminuição da importância dos partidos políticos (Mainwaring, 2001; Baquero, 2000; Manin, 2005). De fato, as pesquisas realizadas nas últimas décadas no Brasil revelam um declínio na confiança do público em relação aos partidos (Moisés, 2005;

DADOS - Revista de Ciências Sociais, Rio de Janeiro, vol. 61, no2, 2018, pp. 503 a 540. 
Meneguello, 2000) e também no nível de filiação ou estabilidade nas preferências partidárias (Pereira, 2014). Segundo Manin (2013), os partidos deixaram de ser sujeitos políticos com identidades definidas e passaram a ser apenas instrumentos dos eleitores, empregados a cada eleição, dependendo das circunstâncias políticas.

Por outro lado, pensadores políticos ressaltam que, apesar das redefinições frequentes, frutos das crises e metamorfoses da democracia (Urbinati, 2013), os partidos políticos ainda conservam algumas características e funções que lhes são peculiares na esfera de pertinência da mediação política e das configurações associativas (Weber, 1999). Segundo Manin, apesar de perderem força em várias áreas, os partidos continuam dominando a política parlamentar e as campanhas eleitorais em todos os países (Manin, 2013). Como registra Ribeiro (2013, p.264), "as elites partidárias não estão inertes: elas têm atuado de modo incisivo para mudar e adaptar as organizações partidárias, principalmente devido a pressões exógenas".

Acerca desse processo de adaptação, Katz e Mair (1995; 2004) ressaltam que as discussões recentes sobre o declínio dos partidos baseiam-se no modelo do partido de massas. Entretanto, os autores chamam atenção para a emergência de outros modelos, a exemplo do partido-cartel, no qual a legislação eleitoral e o sistema de financiamento pelo Estado garantem a sobrevivência das agremiações. Além disso, o Estado atua como agente assegurador da comunicação com o eleitorado, com acesso aos meios de comunicação. Ao recrutar quadros partidários para postos relevantes na administração pública, os autores argumentam que o Estado confere legitimidade às agremiações perante os demais partidos, o parlamento e a própria sociedade. Assim, o modelo de partido-cartel é retroalimentado e fortalecido.

Outra característica apontada pela literatura recente é que os partidos diferem em vários aspectos, mas tendem a convergir quando se trata da centralização na gestão das finanças e dos recursos políticos e da territorialização no que diz respeito à representação de interesses (Bolleyer, 2011). Exemplo de interesses territorializados são as disputas estaduais e municipais (Braga; Pimentel Jr., 2012; Kerbauy, 2012; Braga; Silveira; Borges, 2012; Braga; Speck, 2014; Braga; Costa; Fernandes, 2018). Afinal, "fatores geográficos e estruturais estabelecem cenários que favorecem a constituição de orientações políticas específicas, e associam-se, em alguma medida, a formas locais de organi- 
zação política" (Meneguello; Bizarro Neto, 2012, p.119). A dinâmica local e regional é apontada como um dos fatores que influenciam as coalizões eleitorais (Krause; Dantas, 2010; Limongi; Cortez, 2010; Sandes-Freitas, 2015). Assim, mesmo partidos considerados fracos no cenário nacional podem ter forte atuação política em determinados contexto locais (Guarnieri, 2011).

Especificamente em relação aos partidos de esquerda no Brasil, historicamente, apesar da heterogeneidade de propostas políticas esquerdistas e centro-esquerdistas, essas legendas tiveram suas trajetórias marcadas pela crítica às desigualdades entre capital e trabalho, além de uma pauta comum de reivindicações por transformações profundas nas estruturas econômicas e sociais. A convergência entre ecologismo e socialismo é apontada por Sáiz $(2000 ; 2005)$ como um legado do debate político promovido pelas esquerdas europeias, formando uma esquerda verde, ou seja, uma convergência discursiva em torno de práticas políticas definidas no espaço ideológico do ecosocialismo (Sáiz, 2005, p.64). Cabe verificar como os discursos ecossocialistas são articulados atualmente por essa esquerda verde, por meio de seus programas partidários, os documentos mais relevantes para a compreensão das ideias e propostas dos partidos (Alcántara, 2004; Tarouco; Madeira, 2013; Barros, 2015). ${ }^{1}$

A literatura registra, ainda assim, que os programas partidários constituem uma plataforma que reúne "o corpo de preferências ou intenções do partido" (Tarouco; Madeira, 2013, p.153). Para os autores, tais documentos "tornam-se especialmente válidos como indicativos da posição política dos partidos". Isso equivale a dizer que "a imagem que o partido produz a seu próprio respeito e publica nos seus documentos programáticos seria mais fiel à sua real identidade do que a imagem que os demais atores políticos ou analistas fazem dele" (p.153). Os programas são relevantes ainda como estratégia de competição eleitoral, pois as agremiações "competem enfatizando temas diferentes". Assim, "cada partido seleciona questões de uma agenda universal para concentrar atenção e esforços de campanha, formular propostas de políticas e priorizar nos governos". Logo, cada partido "escolheria enfatizar aquelas questões em que seu desempenho tem mais credibilidade", estabelecendo suas preferências ideológicas e pragmáticas em seus documentos programáticos (Tarouco; Madeira, 2013, p.153).

A decisão de incluir um capítulo sobre ecologia nos programas partidários é considerada um indicativo relevante, expressão de uma tenta- 
tiva de alinhamento com as tendências partidárias internacionais e com a opinião pública nacional. Para o autor, os capítulos ambientais dos programas partidários "muestran progresos en la incorporación de nuevos instrumentos de gestión ambiental, así como el reconocimiento de la necesidad de pensar políticas ambientales integrales y transversales a las demás políticas públicas" (Scagliola 2002,16). Tais argumentos reforçam e justificam a opção pela análise dos programas dos partidos da esquerda verde.

\section{METODOLOGIA}

O levantamento foi realizado no período de agosto a outubro de 2016. A metodologia consistiu em três etapas. Em primeiro lugar foram examinados os programas dos 35 partidos registrados na Justiça Eleitoral, com o propósito de mapear de que forma as temáticas ambientais são incorporadas pelos programas dos partidos em seu conjunto. A segunda etapa consistiu na classificação dos programas partidários quanto à questão ambiental. Conforme exposto no Quadro 1, foram as legendas foram classificadas em três grupos: (a) ambientalistas liberais ${ }^{2}$ (13 partidos); (b) ambientalistas radicais (6 agremiações); (c) ecologistas sistêmicos (2 partidos); (d) e aqueles que ainda não aderiram a nenhum tipo de discurso ecológico (14 legendas). A classificação resultou da análise dos programas partidários na primeira etapa da pesquisa.

A terceira etapa consistiu na análise dos ambientalistas radicais e sistêmicos, os quais foram agrupados no mesmo bloco, devido à proximidade ideológica das propostas. ${ }^{3}$ Essa opção se justifica por se tratar dos partidos que são considerados os fundadores da política verde na arena partidária e os articuladores de uma ideologia ecossocialista ou ambientalismo de esquerda (Sáiz, 2000; 2005; Sainteny, 1994; Duverger 2011). Um dos fatores apontados na literatura para esse protagonismo dos partidos de esquerda na área ambiental foi a rejeição da agenda verde pelos partidos estabelecidos na arena eleitoral, posto que o tema foi estigmatizado durante as décadas de 1960 a 1980, devido às críticas ao sistema industrial, uma das bases do sistema capitalista, fonte de financiamento para as legendas tradicionais. Além disso, os ideais ecológicos de esquerda contrariavam a política econômica liberal da qual os partidos estabelecidos eram atores fundamentais (Sainteny, 1994).

A denominação "esquerda verde" refere-se, na realidade, a uma diversidade de perfis partidários, que se localizam no âmbito do espaço po- 
lítico denominado ecossocialismo, um movimento de convergência entre as políticas socialistas e os movimentos ambientais, com o objetivo de levar as problemáticas ecológicas para o debate sobre políticas públicas de proteção e de conservação da natureza (Sáiz, 2005, p.186). Para o autor, a origem dos partidos ecológicos resulta de dois processos complementares. De um lado, forma-se "um contexto que impulsa la consciência medioambiental y que dá lugar a los movimentos ecologistas". De outro lado, um processo de institucionalização dos movimentos ambientais, o que contribui para o surgimento dos partidos verdes. Tal processo "se consolida em los años setenta y ochenta, extiendendo-se los partidos ecologistas em la maioría de los países europeus, incluindo también los estados del antíguo socialismo real y también algunos del Tercer Mundo" (Sáiz, 2005, p.186).

Os partidos ecológicos passaram a questionar seriamente o modelo capitalista de desenvolvimento econômico, chamando atenção para os aspectos negativos de tal modelo, como a poluição e os danos aos ecossistemas. Em contrapartida, passaram a defender o paradigma do desenvolvimento sustentável, a economia solidária, a proibição do uso de agrotóxicos na agricultura, a recuperação de biomas degradados, entre outras medidas. Assim, o ideal socialista continuou a fazer o seu caminho, articulando cada vez mais a crítica ecológica à sua crítica social original (Duverger, 2011).

Quanto à discussão sobre o espectro ideológico (direita, centro e esquerda), devido à falta de espaço, faremos apenas um breve registro sobre a dificuldade de se lidar com essa classificação devido à polissemia e à dificuldade de fixar fronteiras ideológicas, como registram Bobbio (2001), Giddens (1996), Anderson (2015), Mignolo (2008), Bresser-Pereira (2006), Marenco e Sema (2007), Tarouco e Madeira (2013), (Scheeffer, 2018), entre outros. Do ponto de vista ambiental, que é o foco do estudo, consideramos esquerda verde os partidos que atribuem a causa da atual crise ambiental ao próprio sistema capitalista e que não aceitam as soluções apresentadas pelo ambientalismo liberal que defende a economia verde como solução para a crise ambiental. Isso inclui os ambientalistas radicais e os ecologistas sistêmicos. Tal concepção tem respaldo nos estudos de Sáiz (2000; 2005), Maldonado (2006), Riechmann (2006) e Gudynas (2010). A denominação esquerda verde, entretanto, não expressa uniformidade e visão monolítica sobre as questões ambientais (Lucardie, 1999;2008; 2018).

DADOS - Revista de Ciências Sociais, Rio de Janeiro, vol. 61, no 2, 2018 


\section{Quadro 1}

Partidos Políticos Registrados no TSE

\begin{tabular}{|c|c|c|c|c|}
\hline & Sigla & Legenda & Registro & $\begin{array}{l}\text { Posição no } \\
\text { espectro } \\
\text { ideológico }^{4}\end{array}$ \\
\hline & & AMBIENTALISTAS LIBERAIS & & \\
\hline 1 & PMDB & Partido do Movimento Democrático Brasileiro & 30.6.1981 & Centro \\
\hline 2 & РTB & Partido Trabalhista Brasileiro & 3.11 .1981 & Centro \\
\hline 3 & PT & Partido dos Trabalhadores & 11.2.1982 & Esquerda \\
\hline 4 & DEM & Democratas & 11.9.1986 & Direita \\
\hline 5 & PSB & Partido Socialista Brasileiro & 1E.7.1988 & Esquerda \\
\hline 6 & PPS & Partido Popular Socialista & 19.3.1992 & Esquerda \\
\hline 7 & $\mathrm{PP}$ & Partido Progressista & 16.11.1995 & Centro \\
\hline 8 & PSDC & Partido Social Democrata Cristão & 5.8 .1997 & Direita \\
\hline 9 & PRB & Partido Republicano Brasileiro & 25.8.2005 & Centro \\
\hline 10 & PSD & Partido Social Democrático & 27.9.2011 & Centro \\
\hline 11 & PROS & Partido Republicano da Ordem Nacional & 24.9.2013 & Direita \\
\hline 12 & SDD & Solidariedade & 24.9.2013 & Centro \\
\hline \multirow[t]{2}{*}{13} & PEN & Partido Ecológico Nacional & 19.6.2012 & Direita \\
\hline & & AMBIENTALISTAS RADICAIS & & \\
\hline 1 & PDT & Partido Democrático Trabalhista & 10.11.1981 & Esquerda \\
\hline 2 & PCdoB & Partido Comunista do Brasil & 23.6.1988 & Esquerda \\
\hline 3 & PSTU & Partido Socialista dos Trabalhadores Unificado & 19.12.1995 & Esquerda \\
\hline 4 & PCB & Partido Comunista Brasileiro & 9.5.1996 & Esquerda \\
\hline 5 & $\mathrm{PCO}$ & Partido da Causa Operária & 30.9.1997 & Esquerda \\
\hline \multirow[t]{2}{*}{6} & PSOL & Partido Socialismo e Liberdade & 15.9.2005 & Esquerda \\
\hline & & ECOLOGISTAS SISTÊMICOS & & \\
\hline 1 & PV & Partido Verde & 30.9.1993 & Centro \\
\hline \multirow[t]{2}{*}{2} & REDE & Rede Sustentabilidade & 22.9.2015 & Centro \\
\hline & & PARTIDOS QUE NÃO ADERIRAM À AGEN & NDA VERDI & \\
\hline 1 & PSDB & Partido da Social Democracia Brasileira & 24.8.1989 & Centro \\
\hline 2 & PTC & Partido Trabalhista Cristão & 22.2.1990 & Direita \\
\hline 3 & PSC & Partido Social Cristão & 29.3.1990 & Direita \\
\hline 4 & PMN & Partido da Mobilização Nacional & 25.10 .1990 & Centro \\
\hline 5 & PRP & Partido Republicano Progressista & 29.10 .1991 & Centro \\
\hline 6 & PTdoB & Partido Trabalhista do Brasil & 11.10.1994 & Centro \\
\hline 7 & PRTB & Partido Renovador Trabalhista Brasileiro & 28.3.1995 & Direita \\
\hline
\end{tabular}

(continua) 
A Esquerda Verde: Partidos Políticos e Ambientalismo Radical no Brasil

Quadro 1

(continuação)

Partidos Políticos Registrados no TSE

\begin{tabular}{|lllll|}
\hline Sigla & Legenda & Registro & $\begin{array}{l}\text { Posição no } \\
\text { espectro } \\
\text { ideológico }\end{array}$ \\
\hline 8 & PHS & Partido Humanista da Solidariedade & 20.3 .1997 & Centro \\
9 & PTN & Partido Trabalhista Nacional & 2.10 .1997 & Centro \\
10 & PSL & Partido Social Liberal & 2.6 .1998 & Centro \\
11 & PR & Partido da República & 19.12 .2006 & Centro \\
12 & PPL & Partido Pátria Livre & 4.10 .2011 & Esquerda \\
13 & NOVO Partido Novo & 15.9 .2015 & Direita \\
14 & PMB & Partido da Mulher & 29.9 .2015 & Centro \\
\hline \multicolumn{2}{|l}{ TOTAL $=35$} & & \\
\hline
\end{tabular}

Fonte: Elaboração do autor.

\section{COMO A AGENDA AMBIENTAL FOI INCORPORADA PELOS PARTIDOS POLÍTICOS}

Nas primeiras décadas do século XX, a ecologia ${ }^{5}$ era tratada de forma episódica e fragmentada, mas com o passar do tempo, tornou-se um supertema da agenda social e cultural, especialmente após os anos de 1990, ao romper a lógica de assunto eventual da agenda pública para tornar-se problemática sociopolítica com abordagem continuada, complexa e recorrente (Guimarães, 1996; Barros, 2015). Segundo Ribeiro (2000, p.158), esse processo deve ser analisado à luz de uma tentativa de reeticização do capital, "ao incorporar em seus cálculos a preocupação com as gerações futuras, o conceito de equidade intergerações, de caráter profundamente moral". Desse modo, conforme a análise do mesmo autor, o ambientalismo assumiu a forma de um metarrelato político, uma espécie de formulação universalista, "que articula e neutraliza interesses divergentes no campo político" (p.161). Se antes sua configuração era de uma questão outsider, a penetração difusa das ideias ecológicas na política e nas demais esferas da sociedade, deu-lhe a dimensão de questão estabelecida, que conquistou posição central no debate político, conforme argumenta Ulrich Beck (1994, p.268).

Antes de serem incorporadas aos programas partidários, as pautas ambientais passaram por uma longa e complexa trajetória de variados tipos de militantismo. Diversos ecologismos se formaram antes de chamarem atenção dos partidos políticos (Barros, 2015). Cada vertente possui a sua própria identidade, visto que cada uma delas constitui um

DADOS - Revista de Ciências Sociais, Rio de Janeiro, vol. 61, n² 2, 2018 
campo particular de disputas, com sua natureza própria, seus interesses, suas lógicas e estratégias. O reconhecimento de tal pluralidade é indispensável para evitar o equívoco do pressuposto de um pensamento ecológico único e monolítico (Barros, 2012; 2015).

As recentes (re)configurações do pensamento ecológico são tributárias de um ideário filosófico e político gestado pelos movimentos que defendiam a transformação do pensamento social, da ordem cultural e do sistema político das sociedades avançadas do contexto politico resultante do após II Guerra Mundial (Barros, 2012; 2015). Apesar da pluralidade de vertentes há um escopo político geral que reúne referentes simbólicos comuns que levaram o pensamento ambiental a se tornar um movimento planetário ${ }^{6}$, com ampla visibilidade.

A reflexão fundadora dessa articulação teve como ponto de partida a noção de insustentabilidade da civilização contemporânea. Disso decorre a ideia de que a sustentabilidade será viabilizada social e culturalmente apenas se houver sistemas simbólicos com eficácia para mudar os valores e os comportamentos em um cenário de conflitos e riscos ambientais. Aliás, é oportuno salientar que a conotação política foi acentuada com o debate sobre as questões de risco.

A discussão sobre riscos ambientais carrega consigo uma noção implícita, mas muito relevante para a compreensão sociológica e política contemporânea no que se refere ao conceito de sociedade de risco ${ }^{7}$, uma das abordagens profícuas para a constituição de uma agenda política em nível internacional. ${ }^{8}$ Oficialmente, a preocupação política desses atores internacionais com o meio ambiente, começou a ser expressa nas primeiras décadas do século XX. Mesmo sem a participação expressiva dos grandes partidos, essa fase foi importante, pois contribuiu para criar as condições para o futuro envolvimento da política partidária em nível mais amplo (Barros, 2015).

Alguns países deram os passos iniciais rumo às primeiras medidas de política ambiental no mundo ainda na década de 1970, a exemplo da Austrália, Canadá, Holanda, Suécia e Dinamarca, entre outros. Iniciou-se aí uma longa trajetória de institucionalização da questão ambiental, consagrada politicamente com a criação de órgãos oficiais que potencializaram sua inserção no campo partidário e parlamentar. Assim, o ambiente torna-se um trunfo político, "entrando no jogo institucional da democracia, regido pelos partidos" (Almeida; Premebida, 2014, p.25). Em seguida, os verdes expandiram suas atividades com o 
apoio de ecologistas da Suécia, Finlândia, Noruega, Suíça, Holanda, Alemanha e França. Atualmente, a filosofia orienta partidos políticos em mais de 120 países. Em 2010, o Partido Verde tornou-se a quarta maior bancada no Parlamento Europeu (Barros, 2015).

No contexto europeu, cabe ressaltar a atuação do Partido Socialista (PS) na França, conforme registram Sainteny (1994) e Duverger (2011). A inclusão formal das temáticas ecológicas no programa partidário do PS teve início em 1972. Trata-se de uma experiência partidária singular de adesão à agenda ecológica, o que se deve a um conjunto de fatores, segundo a análise dos autores citados. Em primeiro lugar destaca-se o debate internacional sobre a crise ecológica global, o que fez da agenda verde um elemento expressivo no debate político e uma temática que passou a ser inevitável nas campanhas eleitorais dos candidatos às eleições presidenciais francesas.

O debate sobre desenvolvimento durável proposto pelo PS levou o partido a reforçar a agenda verde no debate político francês e a ressaltar as várias dimensões do discurso ecológico, com ênfase para a articulação entre ecologia política, ecologia social e cultura global. A primeira teria como papel revitalizar a democracia representativa, enquanto as demais exerceriam a função de discutir e apontar novas formas de organização social e de revisão dos sistemas culturais moldados pelo sistema capitalista, pela sociedade de consumo e pelos modelos de crescimento econômico vigentes, de base predatória. Dessa forma, o PS combinou seu discurso de crítica ecológica com a crítica social, política e cultural.

Isso tudo reforçou e ampliou o escopo do debate partidário sobre a agenda verde. Em suma, a ênfase do PS a questões ambientais contribuiu para colocar a agenda ecológica no debate político partidário francês e nos demais países europeus (Sáiz, 2000; 2005). Além de surgir como um novo ator partidário emblemático em sua relação com o ambientalismo, o PS estimulou outras legendas a aderir à agenda verde, especialmente os demais partidos de orientação socialista, reforçando os vínculos históricos e as convergências entre os socialistas e os movimentos sociais ecológicos. Assim, a contribuição do PS é apontada por Sainteny (1994) como a transformação do ecologismo em um eixo de reflexão e de ação política. Isso levou a agenda verde a adquirir relevância também nas eleições legislativas francesas, a partir de 1992. 
Convém ressaltar aqui os fatores internos que influenciaram a adesão dos partidos brasileiros à agenda verde, especialmente no caso do ecossocialismo. Como explicam Alonso, Costa e Maciel (2007, p.167), analisando "articuladamente as dimensões político-institucionais e as simbólicas intervenientes na constituição de um movimento ambientalista no Brasil", observa-se "que ela se explica por duas dinâmicas: a interação dos grupos de ativistas com as estruturas de oportunidades políticas e a articulação deles entre si".

Quanto às estruturas de oportunidades políticas, os autores destacam o processo de redemocratização, a Assembleia Nacional Constituinte de 1987-88 e o contexto político criado pela Rio 92. O primeiro "incentivou a organização de grupos de protestos na sociedade civil, encaminhando a conversão de simpatizantes ambientalistas em ativistas". A Constituinte "compeliu os ativistas a escolherem entre diferentes estratégias de mobilização disponíveis e os levou a convergirem para uma coalizão de associações, em vez de um partido, como forma prioritária de apresentar suas reivindicações na esfera pública". Já a Rio-92 "impingiu à coalizão de associações a negociação de um único frame, cujo significado pudesse ser compartilhado pelo movimento como um todo" (Alonso, Costa e Maciel 2007, 167).

Do ponto de vista da institucionalização dos movimentos ambientalistas e a consequente incorporação de suas pautas pelos partidos políticos no Brasil, um aspecto relevante registrado na literatura diz respeito à atuação dos diretórios estaduais e municipais do $\mathrm{PV}$, a partir do contexto de redemocratização e da promulgação da Constituição de 1988 (Vieira 2016). Se a criação do PV, em 1986, foi motivada por fatores externos, institucionalização e ramificação do partido pelas demais unidades da federação se deu com maior articulação com os movimentos ambientalistas locais e regionais, especialmente na Região Sudeste (Santos 2008). Entretanto, a atuação do PV não se limitou a essas regiões, como demonstra Vieira (2016), ao analisar a institucionalização dos movimentos ecológicos e sua aproximação com o PV na região Nordeste. ${ }^{9}$

Outro aspecto relevante identificado na literatura sobre a institucionalização dos movimentos ecológicos brasileiros ainda durante o regime autoritário, refere-se à interlocução direta desses movimentos com instituições do Estado. A aproximação com o Estado é considerada uma relevante faceta da institucionalização dos movimentos ambientalis- 
tas no Brasil e em países vizinhos, gerando o que Gudynas (1992) denomina como uma extraña pareja. Entretanto, o autor aponta mais dois aspectos igualmente relevantes: em primeiro lugar, a institucionalização não-estatal, com a participação de movimentos ligados a sindicatos, partidos e entidades não-governamentais, e, em segundo lugar, a opção pela não-institucionalização, com a recusa de alguns movimentos a serem cooptados pelo Estado, partidos e outras instituições políticas (Scagliola 2002).

A aproximação dos partidos com os movimentos ambientalistas, contudo, é considerado um fenômeno tardio no Brasil e na América Latina. Segundo a avaliação do autor, em termos ambientais, os partidos têm sido atores políticos secundários:

Los partidos latino-americanos han llegado tarde a la cuestión ambiental: su acción ha sido más reactiva que proactiva, superada tanto por arriba como por abajo por la realidad. Por arriba, a partir de la consolidación de una agenda global que busca contrarrestar los efectos de la degradación del medio ambiente; por abajo, por la emergencia cada vez más recurrente de conflictos ambientales locales. En ambos casos, han prevalecido otros instrumentos de incidencia ciudadana como las redes globales o transnacionales de organizaciones no gubernamentales o las organizaciones vecinales inmersas en conflictos ambientales (Scagliola 2002, p.8).

Apesar de serem reconhecidos como atores secundários, o autor ressalta que houve uma participação significativa, não só dos chamados partidos verdes, como no caso do PV no Brasil, mas também da adesão de outros partidos de esquerda, em função de alianças eleitorais, a exemplo do Partido dos Trabalhadores (PT) e do Partido Verde (PV). Mesmo não sendo um partido ecológico, o PT é apontado na literatura como um partido "con vínculos históricos importantes con el ecologismo" (Scagliola 2002, p.9). Além da criação do Núcleo de Ecologistas do Partido dos Trabalhadores, em 1985, o autor menciona o entusiasmo pessoal de Luiz Inácio Lula da Silva com o tema, ao defender publicamente a inclusão de um capítulo sobre meio ambiente no programa partidário do PT, em 2002 (Scagliola, 2002). ${ }^{10}$

O ambientalismo como alternativa partidária consolida-se, portanto, no contexto brasileiro, como resultado de uma confluência de fatores, como a viabilidade eleitoral, mediante o crescimento do chamado voto verde e a crescente institucionalização das propostas políticas ecológi-

DADOS - Revista de Ciências Sociais, Rio de Janeiro, vol. 61, nº 2, 2018 
cas, fruto da convergência entre movimentos ecológicos e partidos políticos dispostos a abrigar as demandas desses movimentos em seus programas partidários, em função da popularização da agenda ambiental perante a opinião pública (Sáiz, 2014). Logo, a adesão de partidos sem tradição ecológica constituiu uma estratégia pragmática para atuação nas arenas políticas, em função da projeção social dos discursos ambientais e da centralidade do tema nos debates políticos (Martínez, 2015).

Além do PV, os primeiros partidos a incluir formalmente a questão ambiental em seu programa foram o PT e o PSB, ambos motivados pela coligação estadual com o PV para as eleições de 1986 (Viola, 1987). No caso do PT cabe mencionar ainda a influência do Núcleo de Ecologistas do Partido dos Trabalhadores, criado em 1985 (Barros, 2015). Outra onda verde na esfera partidária ocorreu nas eleições de 1994, influenciados pela grande visibilidade do tema durante a Rio 92, destacando-se os partidos de esquerda como o PDT, o PCdoB e o PCB. Os demais, considerados ambientalistas acidentais, passaram a incorporar o tema sob a influência do debate sobre mudanças climáticas, em meados da década de 2000, como o PMDB (Barros, 2018). A maioria dos partidos de orientação ecossocialista radical já nasceram sob a influência da agenda ambiental na esfera partidária, a exemplo do PSTU, criado em 1995; PCB, registrado em 1996; PCO, em 1997 e PSOL, em 2005.

O potencial eleitoral dos partidos ecológicos está diretamente relacionado com a maior visibilidade das questões ecológicas na mídia e a consequente formação de uma consciência pública voltada para a relevância dos problemas ambientais. Trata-se da consolidação da chamada "onda verde", um dos temas principais da agenda pós-materialis$\mathrm{ta}^{11}$, que passou a ter reflexo também no âmbito eleitoral, com a emergência do chamado "voto verde" ou "eleitorado verde" (Franklin; Rüdig, 1992; Economou, 2003; Davis; Wurth; Lazarus; 2008; Nicolet; Hooghe, 2010; Sciarini, 2010).

Os estudos que traçam perfis desse eleitorado mostram que se trata de segmentos distantes das classes populares (Boy; Chiche, 2009). Em sua maioria são jovens, estudantes, residentes em grandes cidades e dotados de um elevado capital cultural e econômico (Hooghe, 2010). Além do ambientalismo, partilham outros valores comuns, de ordem pós-materialista, como defesa da liberdade de expressão e da equidade de gêneros, unindo o verde e o feminismo (Boy, 2002). 
No Brasil, ainda não há estudos sobre o perfil do eleitor verde, mas existem dados sobre a filiação aos partidos. No caso dos ecossocialistas, chama atenção o baixo percentual de filiados às legendas de perfil ecológico, no sentido estrito, como o PEN, PV e Rede, como mostra o Quadro 2.

Quadro 2

A Esquerda Verde e seus Filiados no Brasil

\begin{tabular}{|llll|}
\hline & Partido & N. de Filiados & $\mathbf{\%}^{\mathbf{1 2}}$ \\
\hline 1 & PCdoB & 1.446 .854 & 8,70 \\
2 & PCB & 1.438 .392 & 8,65 \\
3 & PCO & 1.251 .350 & 7,52 \\
4 & PDT & 1.193 .113 & 7,17 \\
5 & PEN & 1.096 .537 & 6,59 \\
6 & PSOL & 122.571 & 0,74 \\
7 & PSTU & 91.077 & 0,55 \\
8 & PV & 14.836 & 0,09 \\
9 & REDE & 8.825 & 0,05 \\
\hline
\end{tabular}

Fonte: Elaboração do autor, com dados do TSE, 2017.

\section{As Temáticas Ambientais nos Programas dos Partidos de Esquerda}

Dos 35 programas partidários examinados, 21 incluem temáticas da agenda ambiental em seus programas, ou seja, $60 \%$. Desses 21 , nove são de esquerda, oito de centro e quatro de direita, como está exposto no Quadro 1. Dos nove de esquerda, apenas um enquadra-se na categoria de ambientalismo liberal (o PT) ${ }^{13}$ Entre os ecossocialistas e os ecologistas sistêmicos, todos dedicam um capítulo do programa partidário às temáticas ambientais, como mostra o Quadro 3, o qual reúne apenas os partidos de orientação ecossocialista, foco deste artigo.

Dedicar um capítulo do programa ao tema é um dado que demonstra como as agremiações valorizam o assunto, visto se tratar de um dos requisitos para que um determinado tema seja visto como expressivo no escopo dos documentos programáticos dos partidos (Tarouco; Madeira, 2013). Isso não significa que todos os partidos analisados atribuam a mesma importância aos mesmos temas ambientais, de forma unânime. Há variações e enfatizações diferenciadas. Entretanto, a existência de um capítulo no programa é um dado objetivo que serve de parâmetro analítico, com respaldo na bibliografia mencionada. 
Quadro 3

Inserção de Temáticas Ambientais nos Programas Partidários

\begin{tabular}{|lcc|}
\hline & PARTIDO & TIPO DE INSERÇÃO NO PROGRAMA \\
\hline ECOSSOCIALISTAS - ESQUERDA RADICAL \\
\hline 1 & PDT & Capítulo \\
& & Capítulo \\
& & Capítulo \\
& & Capítulo \\
& & \\
2 & & Capítulo \\
3 & PCdoB & Capítulo \\
4 & PSTU & \\
5 & PCB & \\
6 & PCO & \\
\hline ECOLOGISTAS SISTÊMICOS - CENTRO-ESQUERDA & \\
\hline 1 & PSOL & Capítulo \\
2 & REDE & Capítulo \\
\hline
\end{tabular}

Fonte: Elaboração própria.

O mapeamento dos temas centrais dos programas partidários acima mencionados, no que se refere à questão ambiental, revelou dois eixos temáticos adotados pelos partidos: (a) as críticas ao sistema capitalista (b) a ecologia sistêmica, que combina ecossocialismo com cultura urbana e cidadania ecológica. Tal mapeamento foi realizado com o auxílio do N-Vivo, um dos recursos mais usados atualmente na análise documental, pela possibilidade de categorização temática por afinidade semântica (Pinho; Rodrigues; Souza; Lopes, 2014). O mesmo software foi utilizado para compilar os termos-chave mais mencionados nos programas, conforme exposto no Quadro 4, com base no pressuposto de que a repetida menção a certos termos expressa relevância, ênfase e significância de tais termos, levando-os a serem considerados categorias relevantes em termos de conteúdo semântico (Bardin, 2004). Esse mesmo critério norteou a seleção dos trechos dos programas que transcritos e comentados na sequência.

Os dois eixos temáticos adotados se relacionam com as dimensões da sustentabilidade, conforme a classificação de Ignacy Sachs ${ }^{14}$ (1993): sustentabilidade econômica, social, ecológica, espacial/geográfica e cultural. Segundo o autor, a sustentabilidade econômica ${ }^{15}$ é focada na 
eficiência na alocação e gestão de recursos extraídos da natureza, além de racionalidade nos investimentos. A sustentabilidade social prioriza políticas de desenvolvimento humano, com o propósito de promover justiça social e reduzir desigualdades. A sustentabilidade ecológica, por sua vez, tem como pilar a preservação das fontes de recursos energéticos e naturais, com base na premissa de que o uso econômico dos bens naturais deve considerar os ciclos temporais inerentes às especificidades de cada ecossistema, a fim de garantir o equilíbrio da biodiversidade. Os programas do PCdoB, PDT, PSOL, PCO, PSTU e PCB conjugam propostas que contemplam as três dimensões da sustentabilidade citada, conforme mostra o Quadro 4.

A sustentabilidade espacial refere-se às políticas para a ocupação do solo e relação campo-cidade, por exemplo. A sustentabilidade cultural consiste no respeito às tradições, comunidades nativas e o patrimônio cultural. Os planos analisados não se detêm em propostas para as duas últimas dimensões. Cabe ressaltar o perfil dos dois partidos tipicamente ecológicos (PV e REDE), os dois únicos que contemplam as cinco dimensões da sustentabilidade. ${ }^{16}$ Para essas legendas as questões ambientais são abrangentes e se inserem em todas as dimensões da vida social, no plano local e global, reunindo o patrimônio natural e a diversidade cultural.

A partir das propostas reunidas na terceira coluna do Quadro 5, é possível identificar dois modelos de governança ambiental defendidos pelos partidos ${ }^{17}$, conforme exposto no Quadro 5.

Os modelos de governança identificados apresentam em comum a defesa de mudanças no sistema produtivo, com vistas à sustentabilidade ambiental, na perspectiva da modernização ecológica (Catton; Dunlap, 1980) e da sustentabilidade econômica (Sachs, 1993). Entretanto, existem diferenças que devem ser ressaltadas. Os críticos ao capitalismo apegam-se a visões marxistas, com um modelo estatal capaz de remodelar o sistema produtivo. Os ecologistas sistêmicos são os defensores de uma ordem ecológica complexa e sistêmica, capaz de religar saberes, políticas e práticas sociais.

Nos dois modelos de governança, o Estado exerce um papel central como ator das políticas ambientais propostas pelos partidos. Trata-se de uma concepção próxima à ideia de Giddens $(2010$, p. 96) de Estado assegurador, ou seja, significa que "o Estado é responsável por monito-

DADOS - Revista de Ciências Sociais, Rio de Janeiro, vol. 61, nº 2, 2018 
Quadro 4

\begin{tabular}{|c|c|c|c|c|c|}
\hline Partidos & $\mathbf{N}$ & Ambientalismo radical & Sustentabilidade correspondente & $\begin{array}{l}\text { Termos-chaves nos programas } \\
\text { partidários }\end{array}$ & $\begin{array}{l}\text { Frequência } \\
\text { Total }\end{array}$ \\
\hline \multirow[t]{10}{*}{\begin{tabular}{|l|} 
PCdoB PDT PSOL \\
PCO PSTU PCB \\
\end{tabular}} & 6 & $\begin{array}{l}\text { Ambientalismo marxista } \\
\text { / Ecossocialismo }\end{array}$ & $\begin{array}{l}\text { Sustentabilidade ecológica, econômica e } \\
\text { social }\end{array}$ & Conservação & 42 \\
\hline & & & & Preservação & 37 \\
\hline & & & & Degradação & 36 \\
\hline & & & & Devastação florestal & 31 \\
\hline & & & & Esgotamentos dos recursos naturais & 27 \\
\hline & & & & Fauna e flora & 27 \\
\hline & & & & Defesa da ecologia & 26 \\
\hline & & & & Qualidade de vida & 19 \\
\hline & & & & Poluição & 18 \\
\hline & & & & Contaminação do solo & 13 \\
\hline \multirow[t]{7}{*}{$\begin{array}{l}\text { PV } \\
\text { REDE }\end{array}$} & 2 & Ecologismo sistêmico & $\begin{array}{l}\text { Sustentabilidade econômica, social, } \\
\text { ecológica, cultural e espacial, Ecologia } \\
\text { política e cidadania ecológica }\end{array}$ & Ecologia política & 14 \\
\hline & & & & Ecologia urbana & 13 \\
\hline & & & & Desarmamento & 12 \\
\hline & & & & Cultura de paz & 11 \\
\hline & & & & Ecodesenvolvimento & 10 \\
\hline & & & & Preservação & 10 \\
\hline & & & & Recuperação ambiental & 10 \\
\hline
\end{tabular}




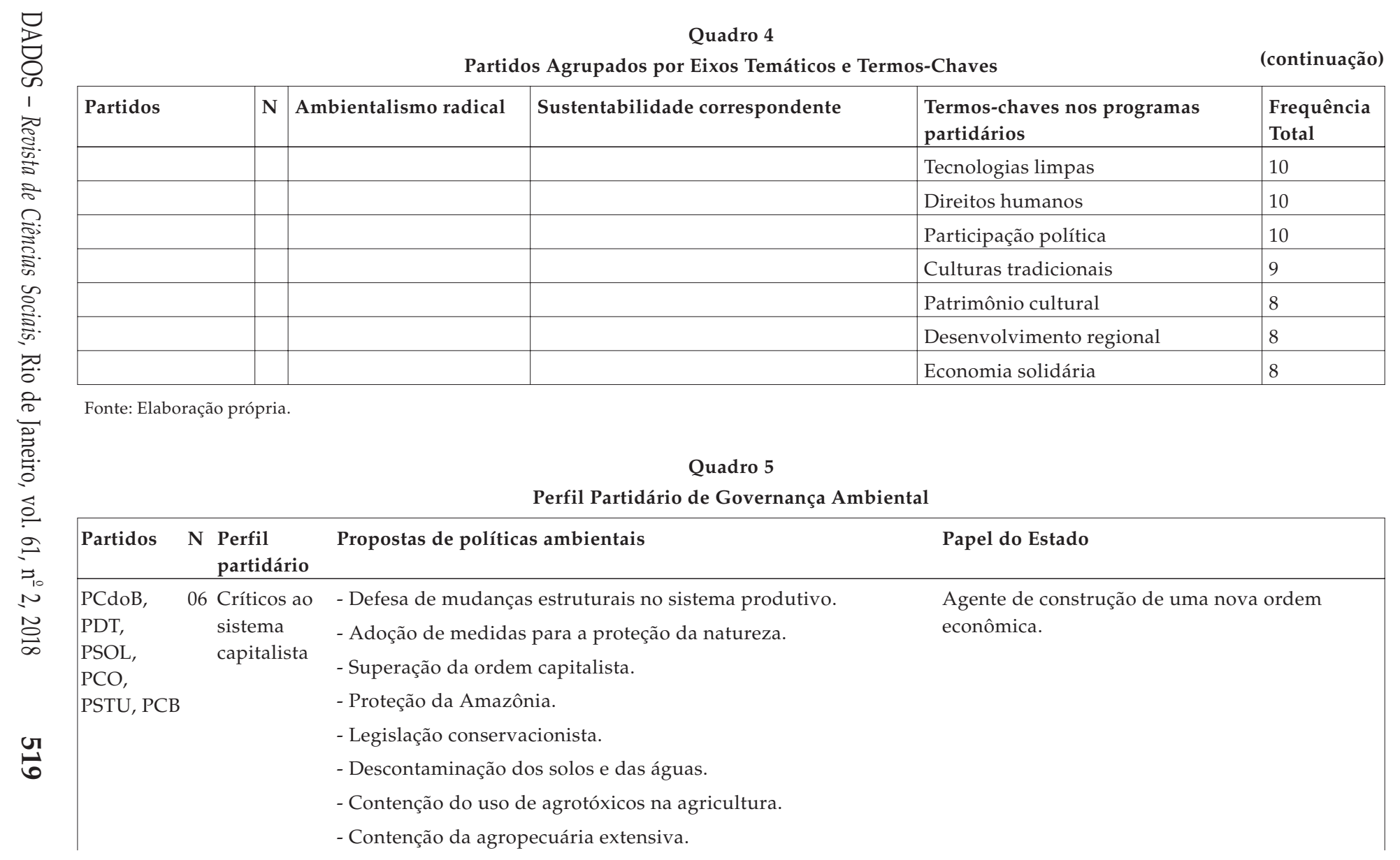


Propostas de políticas ambientais

Papel do Estado

$$
\text { partidário }
$$

PV e PEN 02 Ecologistas sistêmicos em prol da sustentabilidade sistêmica.

Regulador da ecologia política / ecologia

em prol da sustentabilidade sistêmica. urbana e indutor da nova cultura ambiental.

adania ecológica.

- Ecologia como expressão de justiça social e de direitos humanos.

- Adoção de um novo modelo de desenvolvimento de baixo

impacto ambiental.

- Revisão das políticas agrárias.

- Maior integração entre os movimentos ecológicos, as

comunidades tradicionais e os poderes institucionais.

- Adoção de políticas verdes locais e regionais.

- Adoção de programas de combate à miséria, à pobreza e ao desperdício de alimentos.

- Geração de empregos verdes na área de recuperação /

preservação ambiental e desenvolvimento de tecnologias limpas.

Fonte: Elaboração do autor

象 
rar os objetivos políticos e por procurar certificar-se de que eles se concretizem de forma visível e aceitável".

\section{Partidos ecossocialistas}

Seis legendas têm como foco de seu programa partidário, no que se refere à questão ambiental, críticas ao sistema capitalista: PDT, PCdoB, PSOL, PCO, PSTU e PCB. Apesar dessa convergência, em termos gerais, cada partido apresenta suas particularidades, que serão detalhadas abaixo. No caso do $\mathrm{PDT}^{18}$ as propostas são condensadas no sexto compromisso programático de seu programa, numa perspectiva conservacionista e biocêntrica:

O sexto compromisso programático é com a defesa da natureza brasileira, contra a poluição e a deterioração do meio ambiente resultante de uma exploração predatória, que ameaça destruir a base biológica de nossa existência, degradando cada vez mais a qualidade de vida do povo brasileiro (PDT. Compromissos Prioritários, p.1).

O texto confere destaque à proteção da Amazônia:

Depois de empobrecer radicalmente e destruir a fauna e a flora de todas as regiões brasileiras de antiga ocupação, agora ameaçam liquidar com a Amazônia, que é a nossa última reserva da natureza original (PDT. Compromissos Prioritários, p.1).

Uma das propostas concretas diz respeito a uma legislação de cunho mais conservacionista e voltada para coibir a poluição:

O Trabalhismo Democrático propugna por um movimento e uma legislação que defendam o ambiente natural do país e coíbam as diversas formas de poluição e pela implementação de um amplo programa nacional de descontaminação (PDT. Compromissos Prioritários, p.1).

$\mathrm{O} P C \mathrm{CloB}^{19}$ associa o esgotamento dos recursos naturais com "a grande crise do capitalismo da época atual". Segundo o texto, o capitalismo é um sistema esgotado historicamente, que "busca do lucro máximo, e destrói a natureza". Uma das propostas do partido é a transição do capitalismo ao socialismo, com o propósito primordial de "resolver a contradição essencial do capitalismo: produção cada vez mais social em conflito crescente com a forma de apropriação privada da renda e da riqueza" (PCdoB. Programa, sem paginação).

DADOS - Revista de Ciências Sociais, Rio de Janeiro, vol. 61, nº 2, 2018 
O programa do $\mathrm{PCO}^{20}$ apresenta um diagnóstico sobre a crise capitalista, que "resultou na ruína da pequena propriedade, na transformação do produtor em trabalhador assalariado e na monopolização dos meios de produção por um número reduzido de grandes proprietários". Segundo o texto:

A esta monopolização está ligada a eliminação da produção artesanal, a transformação da ferramenta em maquinaria, automatização industrial e a formação do mercado mundial. O capitalismo representou um extraordinário desenvolvimento das forças produtivas do trabalho humano, mas os benefícios deste progresso são totalmente usurpados pelos capitalistas e os grandes proprietários, o que para a classe operária e os setores oprimidos intermediários significa o aumento da insegurança de sua existência, da miséria social, da exploração humana e da degradação ambiental (PCO. Programa Partidário, sem paginação.)

O PSTU adota discurso similar, ao apontar o combate à destruição ambiental como estratégia de "luta contra o capitalismo". O programa da legend $\mathrm{a}^{21}$ assume a função de um manifesto de cunho socialista, com a afirmação de que "combater a destruição ambiental é lutar contra o capitalismo" 22 . Segundo o documento,

A submissão do Brasil à economia capitalista está por trás da destruição do meio ambiente. A demanda cada vez maior por matérias primas provocou a expansão da exploração da mineração e das monoculturas de soja, cana de açúcar, eucaliptos etc. O agronegócio avançou por todo o Cerrado e agora se expande para a Amazônia. Esse avanço fez com que o Brasil se tornasse o maior consumidor de agrotóxicos do mundo. Por aqui, é permitida a utilização até dos agrotóxicos que foram banidos em outros países. O resultado é a contaminação dos alimentos, da água e do solo por substâncias químicas maléficas à saúde humana (PSTU. Programa Partidário, sem paginação).

Outro trecho aponta a incompatibilidade entre a lógica capitalista e os princípios ecológicos:

O uso irracional dos recursos naturais tem provocado a destruição do meio ambiente em proporções gigantescas. Voltada para os lucros imediatos, a exploração capitalista se move por uma lógica de curto prazo, o que é incompatível com o tempo de recuperação da natureza. O resultado tem sido a contaminação do solo, do ar e da água, a devastação das florestas tropicais, o aumento da temperatura do planeta e o esgota- 
mento dos recursos necessários à sobrevivência humana (PSTU. Programa Partidário, sem paginação.)

O programa partidário do $\mathrm{PCB}^{23}$ é sucinto quanto à questão ambiental e limita-se a uma breve crítica ao modelo de desenvolvimento capitalista, "que ameaça não apenas os trabalhadores, mas a própria vida humana, numa irracional exploração dos recursos naturais e sociais que são necessários à reprodução da vida" (PCB. A formação histórica do capitalismo, p.1).

O PSOL ${ }^{24}$ insere a questão ecológica no contexto mais amplo do socialismo, como princípio estratégico na superação da ordem capitalista. Dessa forma, o partido propõe:

A construção de um ideário de superação do processo capitalista reúne hoje, além dos tradicionais pressupostos socialistas, um grande impulso ainda mais vital ligado à questão ecológica. Esse fator pode contribuir decisivamente na reorganização dos trabalhadores internacionalmente. Tendo claro que as forças de destruição irracionais acumuladas pelo sistema ameaçam o conjunto da humanidade e da vida no planeta, de tal forma que a luta contra o capitalismo significa a luta em defesa da ecologia, do meio ambiente e da vida, o novo partido elaborará sua plataforma ecológica com a intervenção direta do movimento ecológico nos próximos meses (PSOL. Programa Partidário, sem paginação).

O documento do PSOL apresenta um capítulo denominado "Política econômica e modelo de desenvolvimento", no qual defende que a proposta de a construção de um novo modelo econômico requer "uma profunda revisão do sistema agrário brasileiro". Além de uma reforma agrária profunda,

que desmonte o latifúndio e desaproprie propriedades que possam ser utilizadas para fins produtivos - sobretudo a produção de alimentos será papel do Estado incentivar atividades que gerem empregos, desenvolvam de forma sustentável a economia no campo e fortaleçam a soberania nacional (PSOL. Programa Partidário, sem paginação).

O PSOL apresenta como diferencial a prioridade no que se refere às políticas agrárias de desenvolvimento, ao resgatar uma antiga bandeira dos partidos de esquerda. Mais uma vez, a figura do Estado assegurador é central, mas com o propósito específico de regular e institucionalizar planos de reforma agrária para o campo, a fim de aumentar a produção de alimentos e promover o desenvolvimento local e regional.

DADOS - Revista de Ciências Sociais, Rio de Janeiro, vol. 61, n² 2, 2018 
Duas representações do ambiente rural são evocadas e contrapostas: 0 cenário atual, marcado pelo latifúndio improdutivo e um possível cenário futuro, de pequenas propriedades produtivas, como base na reestruturação das políticas econômicas face às novas posturas ecológicas, com a ambientalização das práticas agrícolas campesinas.

A posição ideológica dos partidos de orientação comunista e socialista apresenta algumas convergências com a análise de Sainteny (1994) e Duverger (2011). Além disso, reflete parte das críticas fundamentadas na concepção de ecologia política, segundo a qual o discurso da sustentabilidade mudou o foco da exploração capitalista do homem para a natureza (Latour, 1994; 1999). A crítica feita pelos partidos, nessa perspectiva "torna-se um recurso, uma competência entre outras, a gramática de nossas indignações" (Latour, 1994, p.49). Uma limitação dessa vertente, na visão do mesmo autor, é a abordagem totalizante, pois esses críticos tratam a natureza e o sistema político como uma totalidade. Por essa razão, a ecologia política perdeu força e tornou-se marginal, "porque não compreendeu ainda nem sua política, nem sua ecologia" (Latour, 1999, p.48).

Esses partidos conjugam sustentabilidade econômica, social e ecológi$\mathrm{ca}$, mas apenas no plano retórico, pois não apresentam propostas específicas de governança ambiental. Em suma, os programas partidários ecossocialistas assemelham-se mais a manifestos anticapitalistas do que a programa de governança ambiental propriamente dito. Entretanto, o manifesto é coerente com a identidade e a trajetória dessas agremiações, cujo objetivo primordial é marcar posição no contexto da concorrência partidária e não propor governança efetivamente, visto que apresentam poucas chances de eleger candidatos para cargos executivos, como presidente da República ou governador.

\section{Partidos Ecologistas Sistêmicos}

Os dois partidos de orientação tipicamente ecológica enquadram-se nesse eixo temático: PV e Rede. Apesar de apresentarem programas específicos, ambos convergem para alguns aspectos gerais do debate ambiental. Na abertura do texto que institui o programa partidário ${ }^{25}, \mathrm{o} P \mathrm{PV}$ é definido como "um instrumento da ecologia política", em articulação com os demais partidos e com os movimentos verdes de outros países, o que reitera aspectos de sua história, no que se refere aos vínculos com os movimentos ecológicos europeus. Em termos mais amplos, a 
proposta da legenda é "desenvolver uma estratégia conjunta e uma ação coordenada em favor do desarmamento, da desnuclearização, do ecodesenvolvimento, da solução negociada dos conflitos e do respeito às liberdades democráticas, justiça social e direitos humanos".

O programa conexão do PV com o movimento ecologista, as comunidades locais e os poderes institucionais:

O PV luta pelo fortalecimento do movimento ecologista e pela realização das suas propostas. Funciona como um canal de ação política, no campo institucional, para servir o ambientalismo, sem pretensões hegemônicas ou instrumentalizantes. O PV participa, através dos seus militantes, dos movimentos sociais, culturais e das organizações não governamentais. O PV deve organizar-se junto às comunidades locais, obter o poder através dos diversos níveis do legislativo e executivo, para a execução do programa verde no plano local, regional e nacional (Partido Verde. Programa partidário, sem paginação).

O texto reitera ainda a estreita relação entre a questão ambiental e a questão social. "Os problemas tanto sociais como ambientais devem ser tratados numa perspectiva integrada e sistêmica para realmente terem efeito sobre a qualidade de vida da população". Isso significa que

a simples preocupação conservacionista da natureza, sem uma sensibilidade social aliada à incapacidade de apontar modelos de desenvolvimento sustentável só pode agravar a miséria e abrir caminho a uma devastação ambiental ainda maior no futuro. Os verdes propugnam o desenvolvimento sustentável como caminho para combater a miséria e o desperdício. Isso significa gerar trabalho e empregos de forma intensiva na preservação e recuperação ambiental e desenvolver novos setores da economia baseados em tecnologias limpas (Partido Verde. Programa partidário, sem paginação).

O caminho apontado pelo PV para a superação das contradições implicadas na agenda socioambiental é a educação para a cidadania e o ecodesenvolvimento:

O principal obstáculo a um desenvolvimento sustentado e a uma democracia plena no país é o cada vez mais baixo nível educacional e cultural das sucessivas gerações que passam pelo ou ao largo do sistema educacional vigente. A degradação do sistema educacional, sua incapacidade de formar cidadãos e também servir de base para uma valorização profissional adequada prejudica notavelmente a consolidação

DADOS - Revista de Ciências Sociais, Rio de Janeiro, vol. 61, nº 2, 2018 
de uma sociedade solidária e de uma economia capaz de criar o máximo de valor agregado, o que depende de mão de obra qualificada (Partido Verde. Programa partidário, sem paginação).

O PV apresenta ainda propostas setorizadas por áreas como energia renovável, economia verde, poder local, Agenda 21, qualidade de vida, saúde, reforma agrária, combate à fome e à pobreza.

O programa da Rede apresenta muitas convergências com as ideias e propostas do PV, sob a perspectiva de considerar a ecologia sob uma perspectiva sistêmica. Segundo o texto do programa partidário da REDE:

Sustentabilidade é o coração, a visão e a missão da REDE - é o seu nome próprio. Como entender a essencialidade deste termo para o alcance profundo de nossa visão (utopia) e amplitude de nossa missão (prática)? Sugerimos a expressão por inteiro para demonstrar que a sustentabilidade é integral e sua realização vai além da junção mecânica de diferentes aspectos. A REDE formula 7 níveis de sustentabilidade ambiental, social, cultural, ética, estética, econômica e política, os quais incluem de forma transversal as sustentabilidades individual e coletiva e um importante componente de resiliência psico-espiritual. Assim, as 7 dimensões da sustentabilidade que a Rede abraça estão permeadas pela capacidade de realização plena do indivíduo e da sociedade, aumentando assim nossa própria capacidade de afastar as formas de corrupção pessoal ou sistêmica (Descobrindo Valores e Competências Essenciais. Rede Sustentabilidade, 2016, p.6.)

Ainda segundo o texto:

É preciso garantir a capacidade da natureza de se reproduzir e evoluir, por meio do cuidado à manutenção dos ciclos biogeoquímicos e da energia que dão sustentação a todas as formas de vida. Isso só é possível transformando a relação entre os seres humanos e entre estes e o ambiente natural, o que também supõe levar em conta o direito das gerações futuras a um planeta não degradado. É preciso dar ênfase à questão climática como um eixo onde se encontram as várias dimensões da sustentabilidade, demonstrando a necessidade de visão e ação integradas (Descobrindo Valores e Competências Essenciais. Rede Sustentabilidade, 2016, p.6.)

As relações econômicas, segundo o documento, "devem estar baseadas em valores humanos e promover bem-estar em a toda sociedade, 
gerar conhecimentos, oportunidades de trabalho e riqueza, o que não se manifesta apenas através de parâmetros monetários e administrativos" (p.7). A cultura econômica, segundo o partido, deve internalizar os valores de qualidade de vida e equidade em lugar do consumismo e da desigualdade e "promover a adequação dos objetivos do mercado aos direitos humanos e à justiça social, rejeitando a naturalização da supremacia das razões econômicas sobre todas as demais" (p.7). O PV e a REDE convergem em termos de ecologia sistêmica e albergam variadas dimensões da sustentabilidade, com propostas de ações integradas e coordenadas.

\section{CONCLUSÕES}

O objetivo do artigo foi analisar o perfil e as propostas dos partidos políticos brasileiros que defendem o ambientalismo radical, conhecido na literatura como ecossocialismo. Para tanto, analisamos como as ideias ecossocialistas são articuladas nos programas partidários, que aspectos são enfatizados, quais as propostas políticas apresentadas, o perfil de governança ambiental defendido e a noção de sustentabilidade que orienta os discursos ecossocialistas. No âmbito da chamada esquerda verde, apesar das variações internas, foram identificados dois perfis de partidos ecossocialistas: os radicais e os sistêmicos.

No primeiro grupo, temos as seguintes legendas: PDT, PCdoB, PSTU, PCB, PCO e PSOL. Apesar das diferenças programáticas mais amplas, no que se refere especificamente à questão ambiental, tais agremiações apresentam em comum um discurso de crítica ao sistema industrial capitalista e apontam o socialismo como alternativa para a construção de políticas efetivamente sustentáveis do ponto de vista ecológico.

Os ecossocialistas defendem maior centralidade das políticas de preservação, a partir de uma visão biocêntrica de patrimonialização da natureza, segundo a qual o Estado deve ampliar o número de unidades de conservação e manter algumas áreas florestais intocadas. Esses partidos dão ressonância às ideias de movimentos de base conservacionista, cujos líderes foram cientistas e naturalistas defensores da preservação de paisagens, recursos naturais e espécies animais e vegetais (Pádua, 1990; Oliveira, 2008).

Quanto ao segundo grupo, formado pelo PV e Rede, a visão de ecologia é mais sistêmica e abrangente. Ambos não enfatizam tanto a dicotomia entre direita (liberalismo econômico) e esquerda (ecossocialismo),

DADOS - Revista de Ciências Sociais, Rio de Janeiro, vol. 61, nº 2, 2018 
mas uma visão que integra a sustentabilidade ecológica com as demais dimensões da vida social, cultural e política. Os ecologistas sistêmicos pregam transformações sociopolíticas e culturais amplas, associando democracia e cidadania ecológica. As pautas defendidas pelos programas partidários desse segmento são amplas, incluindo temas como cultura de paz, desarmamento, igualdade e justiça social, direitos humanos, desenvolvimento regional e economia solidária. Ao ser incorporado aos programas partidários, o discurso crítico assume a forma de manifesto contra o sistema industrial vigente, associado aos seguintes termos: poluição, degradação, devastação, contaminação do solo e esgotamento dos recursos naturais.

Os partidos que são associados diretamente à causa ecológica, como o PV e a REDE, assumem um discurso vinculado ao debate sobre ecologia política, ecologia urbana e cidadania ecológica. São termos muito amplos, cujos sentidos são depreendidos a partir dos termos-chave que aparecem com mais ênfase nos respectivos programas partidários, tais como: ecodesenvolvimento, movimentos ecológicos, qualidade de vida, preservação e recuperação ambiental, tecnologias limpas, legislação ambiental, unidades de conservação, reciclagem e coleta seletiva.

Nos dois perfis, com suas diversidades de visões de ambientalismo, de sustentabilidade e de governança ecológica, mas o Estado é visto pelos partidos como um ator que deve ser instrumentalizado para a execução das propostas ecológicas, segundo a concepção de Giddens (2010), no que se refere ao Estado assegurador. A centralidade do papel do Estado é um aspecto que chama atenção nas propostas constantes nos programas partidários analisados. O Estado é idealizado por essas agremiações como guardião das políticas de preservação, indutor da sustentabilidade e de uma nova cultura ambiental, além de agente de construção de uma nova ordem econômica. O Estado é legitimado pelo discurso das legendas em exame como ator chave no processo de formulação e de implementação das políticas públicas setoriais na área ambiental.

As ideias de governança ambiental apresentadas pelos partidos ecossocialistas vinculam-se principalmente às funções reguladoras do Estado, com a atuação para promover mudanças estruturais no sistema produtivo, na matriz energética e na transição de uma economia que prima pelos valores de mercado para uma economia orientada pelas prioridades 
estabelecidas na esfera estatal. Enquanto os ecossocialistas supervalorizam o papel do Estado, as legendas de visão sistêmica, embora também defendam o modelo já mencionado de Estado assegurador, colocam a sociedade como coautora e cogestora das políticas ambientais, por meio da participação cidadã ativa nos processos decisórios relativos à formulação e fiscalização das políticas ambientais.

Cabe reiterar que a inserção das pautas ambientais na agenda e no programa dos partidos políticos de esquerda deve ser compreendida como um fenômeno social e culturalmente construído, ou seja, resultante das relações entre os diferentes sujeitos e atores sociais e políticos, representados por múltiplos polos de interesse, tais como a sociedade civil, os movimentos sociais e a comunidade científica, como foi ressaltado na primeira parte do texto. Ao deixar de ser uma questão outsider e se tornar uma questão estabelecida (Giddens, 2010), a agenda verde foi incorporada gradativamente ao discurso político partidário como forma de assegurar espaço na arena eleitoral e de reforçar sua identidade. Trata-se de uma tentativa de construir uma narrativa política associada à sustentabilidade, a fim de conquistar segmentos do eleitorado que se identificam com a temática ou reforçar sua identidade ecossocialista (BARROS, 2015).

Submetido em 27 de março de 2018 Aprovado em 30 de julho de 2018 


\section{NOTAS}

1. Ribeiro (2013) destaca também a importância dos estatutos, mas devido à sua relevância para a compreensão da estrutura organizativa dos partidos.

2. O ambientalismo liberal ou capitalismo verde reúne as correntes baseadas nos princípios do liberalismo econômico (Farhir Neto, 2006), enquanto o ambientalismo marxista (ambientalismo radical ou ecossocialismo) aponta o capitalismo como responsável pela crise ambiental.

3. A pesquisa é mais ampla e pretende analisar os ambientalistas liberais em outro artigo.

4. Usamos aqui a classificação de Tarouco e Madeira (2013), cujo trabalho examinou a literatura pertinente ao assunto, priorizando a análise dos programas partidários para definir a posição de cada um no espectro ideológico. De forma complementar também usamos a classificação de Scheeffer (2018) focada na atuação parlamentar.

5. Cabe esclarecer que o termo inicial utilizado para se referir ao pensamento verde era "ecologia". Com o passar do tempo, passou-se a preferir "ambientalismo". Conforme Pádua (1986), o sentido do primeiro situava-se mais no campo do meio natural, enquanto o segundo passou a englobar a cultura e a sociedade. Em suma, no primeiro caso havia certa conotação de externalidade (mundo exterior), enquanto o segundo inclui o homem, a cultura, a sociedade. É nesta acepção que os dois conceitos são utilizados.

6. O discurso ecológico amplificou-se a partir das convergências e antinomias peculiares às suas diversas vertentes, desde as mais radicais àquelas que aderiram às retóricas conciliadoras do "capitalismo verde", sob a nomenclatura de desenvolvimento sustentável.

7. Termo cunhado por Ulrich Beck para designar uma etapa da modernidade ou uma "segunda modernidade" que emerge da globalização e tem como consequências uma cadeia interrelacionada de riscos sociais, econômicos, políticos e ambientais, que se expressam no consumismo, individualismo, miséria, fome, violência e desastres nucleares, químicos e genéticos.

8. Embora o termo "risco" tenha surgido no repertório sociológico em 1986, com a publicação da primeira edição do livro de Beck sobre sociedade do risco (Risikogesellschaft, em alemão), os organismos internacionais já chamavam atenção para as catástrofes ecológicas desde o início da década de 1920, como mostra o Quadro 2.

9. O PV foi fundado em 1986, na cidade do Rio de Janeiro, resultado da reunião de ex-exilados políticos, como ecologistas, artistas, intelectuais e ativistas do movimento antinuclear.

10. Segundo Barros (2015), o PT mudou sua orientação ecossocial radical para centro-esquerda liberal em termos ambientais, a partir da eleição de Lula em 2002. Isso significa que assumir o governo mudou o eixo do discurso ambiental do PT: de crítico ao capitalismo passou a propor medidas ambientais economicamente viáveis, em sintonia com o crescimento econômico do país.

11. A distinção entre agenda materialista e pós-materialista decorre da análise de Inglehart (1988) acerca de reconfigurações dos valores políticos em função de mudanças geracionais e dos avanços econômicos e políticos nas democracias avançadas. Nessa perspectiva, as prioridades teriam evoluído das questões materiais para 
aquelas denominadas pós-materiais, como a liberdade de expressão, a igualdade entre gêneros e raças, o desenvolvimento sustentável, a liberdade religiosa e demais valores culturais e simbólicos. Em muitas democracias em desenvolvimento, como é o caso do Brasil, essas duas ordens de valores coexistem e disputam a atenção dos partidos e dos eleitores.

12. Os percentuais se referem ao total de filiados no Brasil, ou seja: 16.630 .650 , segundo dados do TSE, 2017.

13. Devido a essa razão, o PT foi incluído em outro artigo que trata dos partidos de orientação ecológica liberal, ainda em elaboração.

14. O autor destaca cinco dimensões do desenvolvimento sustentável: social, econômica, ecológica, espacial/geográfica e cultural. A sustentabilidade espacial refere-se às políticas para a ocupação do solo e relação campo-cidade, por exemplo. A sustentabilidade cultural consiste no respeito às tradições, comunidades nativas e o patrimônio cultural.

15. É importante destacar que tal concepção, surge no âmbito do conceito de desenvolvimento sustentável, cuja matriz é o projeto desenvolvimentista liberal aplicado ao meio ambiente. “Desde a Conferência de Estocolmo, em 1972, ficou claro que a preocupação dos organismos internacionais quanto ao meio ambiente, era produzir uma estratégia de gestão desse ambiente, em escala mundial, que atendesse a sua preservação dentro de um projeto desenvolvimentista. Dentro dessa perspectiva produtivista, o que se queria preservar de fato era um modelo de acumulação de riquezas em que o patrimônio natural passava a ser um bem" (Carvalho, 1991, p.11). Trata-se, portanto, nas palavras de Boaventura Sousa Santos (2010, p.275), de um “processo de politização do espaço da produção".

16. No caso do PV e REDE cabem algumas observações sobre a história e as lógicas específicas de atuação de cada um deles, o que auxilia na compreensão do vínculo dessas duas legendas com a agenda verde atual. O PV foi criado em 1986, sob influência de movimentos ecológicos internacionais que defendiam o pacifismo, a justiça social, a cultura de paz e a igualdade social. Seu discurso tem como base a ecologia política e social de forma abrangente (Barros, 2015). A REDE foi criado em 2015, com o propósito de apresentar-se como uma alternativa específica para a formulação de políticas de sustentabilidade em nível nacional (Oliveira, 2012; Barros, 2015).

17. Os dois modelos de governança aqui apresentados foram categorizados a partir da análise documental, com base no texto dos programas partidários.

18. Disponível em http://www.pdt.org.br/index.php/pdt/programa/1-compromissos-prioritarios

19. Disponível em: http://www.pcdob.org.br/documento.php?id_documento_arquivo $=1$

20. Disponível em: http://www.pco.org.br/pco/programa.htm

21. Disponível em: http://www.pstu.org.br/node/20868

22. A íntegra do manifesto também foi publicada no jornal do PSTU, intitulado Opinião Socialista $n^{\underline{0}} 482$.

23. Disponível em: http://www.pcb.org.br/portal/docs/historia1.pdf

24. Disponível em: http://www.psol50.org.br/site/paginas/2/programa

25. Disponível em: http://pv.org.br/opartido/programa/

DADOS - Revista de Ciências Sociais, Rio de Janeiro, vol. 61, nº 2, 2018 


\section{REFERÊNCIAS BIBLIOGRÁFICAS}

ALCÁNTARA, Manuel. (2004). ¿Instituciones o máquinas ideológicas? Origen, programa y organización de los partidos políticos latinoamericanos. Barcelona: Institut de Ciènces Polítiques i Sociales.

ALMEIDA, Jalcione; PREMEBIDA, Adriano (2014). Histórico, relevância e explorações ontológicas da questão ambiental. Sociologias, vol.16, n.35, p. 14-33.

ALONSO, Angela; COSTA, Valeriano (2002). Ciências Sociais e Meio Ambiente no Brasil: um balanço bibliográfico. BIB - Revista Brasileira de Informações Bibliográficas em Ciências Sociais, n. 53, 1o. semestre de 2002, pp.35-78.

ALONSO, Angela; COSTA, Valeriano; MACIEL, Débora (2007). Identidade e estratégia na formação do movimento ambientalista brasileiro. Novos Estudos-CEBRAP, n.79, p.151-167.

AMARAL, Oswaldo E. (2013). O que sabemos sobre a organização dos partidos políticos: uma avaliação de 100 anos de literatura. Debates, Porto Alegre, v.7, n.2, p.11-32.

ANDERSON, Perry. (2015) Espectro: da direita à esquerda no mundo das ideias. São Paulo: Boitempo Editorial.

BAQUERO, Marcelo (2000). A vulnerabilidade dos partidos políticos e a crise da democracia na América Latina. Porto Alegre: Ed. Universidade/UFRGS.

BARDIN, Laurence (2004). Análise de conteúdo. Lisboa: Edições 70.

BARROS, Antonio T. (2012). Dimensão filosófica e política do pensamento ambiental contemporâneo. Veritas, Porto Alegre, v.57, n.1, p. 92-111.

. (2013). A visibilidade ambiental em perspectiva sociológica: estudo comparado Brasil-Portugal. Sociologias, v. 15, p. 318-345.

BARROS, A. T.; BERNARDES, C. B. RODRIGUES, M. R. (2014). Palanques virtuais: o uso de websites pelos partidos políticos brasileiros. 38․ Encontro Anual da Anpocs. Anais ...

BARROS, Antonio T. (2015). Política partidária e meio ambiente: a adesão dos partidos políticos brasileiros à agenda verde. Opinião Pública 21, no. 3: 693-733.

BAUMAN, Z. (2000). Em busca da política. Rio de Janeiro: Zahar.

BOY, Daniel. (2002). Le Vert et le Rose: le poids de l'environnement et du social chez les militants Verts français.

BOY, Daniel; CHICHE, Jean. (2009). Une vague verte? Revue internationale de politique comparée, v. 16, n. 4, p. 623-635.

BRAGA, Maria do Socorro S.; PIMENTEL JR., Jairo. (2013). Estrutura e organização partidária municipal nas eleições de 2012. Cadernos Adenauer, v.14, 2, p. 13-36.

BRAGA, Maria do Socorro S.; RODRIGUES-SILVEIRA, Rodrigo; BORGES, Tiago. (2012), Organización, territorio y sistema partidario: difusión territorial de la organización de los partidos y sus potenciales impactos sobre la estructura del sistema partidario en Brasil. América Latina Hoy, 62: 15-45. 
BRAGA, Maria do Socorro S. \& SPECK, B. (2014), Organização partidária e carreiras políticas no nível local. Anais do XII Encontro da Brazilian Studies Association (BRASA). King's College London, 20-23 de agosto.

BRAGA, Maria do Socorro Sousa; COSTA, Valeriano M.; FERNANDES, J. Lucas M. (2018) Dinâmicas de funcionamento e controle do poder nos partidos políticos: os casos do PT e PSDB no estado de São Paulo. Revista Brasileira de Ciências Sociais, v.33, n.96.

BOBBIO, Norberto. (2001) Direita e Esquerda razões e significados de uma distinção política. São Paulo: EdUnesp.

BOBBIO, Norberto (1992). A era dos direitos. Rio de Janeiro: Campus.

BOLLEYER, Nicole (2011). New party organizatiom in Western Europe: of part hierarchies, stratarchies and federations. Party Politics, p. 315-336.

BECK, U.; GIDDENS, A. ; LASH, S. (1994) Modernização Reflexiva: política, tradição e estética na ordem social moderna. São Paulo: Editora da Universidade Estadual Paulista.

BRESSER-PEREIRA, Luiz Carlos (2006). O paradoxo da esquerda no Brasil. Novos Estudos-CEBRAP, 74: 25-45.

BUTTEL, F.H. (2000) Ecological modernization as social theory. Geoforum, Oxford, v.31, p.57-65.

CATTON, W. R.; DUNLAP, R. E. (1980) A New Ecological Paradigm for Post-Exuberant Sociology. American Behavioral Scientist, vol. 24, n. 1, set./oct., p. 15-47.

CARREIRÃO, Yan e KINZO, Maria das. G. (2004). Partidos políticos, preferência partidária e decisão eleitoral no Brasil (1989/2002). Dados, vol. 47, n. 1, p. 131-168,

CARVALHO, Isabel. C. M. (2006) as transformações na esfera pública e a ação ecológica. Revista Brasileira de Educação, v. 11, n.32, p.308-315.

CASTELLS, M. (1999) O poder da identidade, Rio de Janeiro: Paz e Terra.

(2003) A galáxia da internet. Rio de Janeiro: Zahar.

DAVIS, Frank L.; WURTH, Albert H.; LAZARUS, John C. (2008) The green vote in presidential elections: Past performance and future promise. The Social Science Journal, v.45, n.4, p.525-545.

DUVERGER, T. (2011). Le Parti Socialiste et l'écologie - 1968-2011. Paris: Jean Jaurés Fondation.

ECONOMOU, Nick et al. (2003) Who voted Green?: A review of the Green vote in the 2002 Victorian state election. People and Place, v.11, n.3, p.57.

FARHI NETO, Leon. (2006) Concepções filosóficas ambientalistas: uma análise das diferentes perspectivas.ethic@-An international Journal for Moral Philosophy 5, no. 3:33-56.

FIGUEIREDO, E. (1993) Angústia ecológica e o futuro. Lisboa: Gradiva.

FLEURY, Lorena Cândido; ALMEIDA, Jalcione; PREMEBIDA, Adriano. (2014) O ambiente como questão sociológica. Sociologias. v. 16, n.35, p. 34-82.

FRANKLIN, Mark N.; RÜDIG, Wolfgang. (1992) The Green voter in the 1989 European elections. Environmental Politics, v.1, n.4, p. 129-159.

DADOS - Revista de Ciências Sociais, Rio de Janeiro, vol. 61, n² 2, 2018 


\section{Antonio Teixeira de Barros}

GIDDENS, Anthony. (1996) Para além da esquerda e da direita: o futuro da politica radical. São Paulo: Unesp.

GIDDENS, A. (2010) A política da mudança climática. Rio de Janeiro: Zahar.

GOMES, W. (2004) Transformação da política na era da comunicação. São Paulo: Paulus.

GUARNIERI, Fernando. (2011) A força dos partidos 'fracos'. Dados, v.54, n.1, p.235-258.

GUDYNAS, Eduardo. (2010) Si eres tan progresista ¿ por qué destruyes la naturaleza? Neoextractivismo, izquierda y alternativas. Quito: Centro Andino de Acción Popular, p. 61-82.

GUIMARÃES, R. P. (1986) Ecopolitics in the Third World. University of Connecticut.

GUDYNAS, Eduardo. (1992) Una extraña pareja: los ambientalistas y el Estado en América Latina. Ecología Política, n.3, p. 51-642.

HABERMAS, J. (1995) O Estado-nação europeu frente aos desafios da globalização. Novos Estudos CEBRAP, São Paulo, n.43, p.87-101.

HOBSBAWN, Eric. (1995) A era dos extremos. São Paulo: Companhia das Letras.

HOOGHE, Marc et al. (2010) Explaining the Green vote: Belgian local elections, 1994-2006. Environmental Politics, v. 19, n. 6, p. 930-950.

INGLEHART, R. (1998) Modernización y postmodernización: el cambio cultural, económico y político en 43 sociedades. Madrid: Siglo XXI.

KATZ, Richard S.; MAIR, Peter. (1995) Changing models of party organization and party democracy: the emergence of the cartel party. Party politics, v. 1, n. 1, p. 5-28.

KATZ, Richard S.; MAIR, Peter. (2004) El partido cartel. La transformación de los modelos de partidos y de la democracia de partidos. Zona Abierta, n. 108/109, p. 9-42.

KERBAUY, Maria Teresa Miceli \& ASSUMPÇÃO, Raiane. (2012), “Análisis organizacional del Partido de la Democracia Social Brasileña en el Estado de San Pablo (1988-2006)". América Latina Hoy, 62: 79-101.

KEY, V. O. (1964) Politics, Parties and Pressure Groups. New York: Crowell.

LATOUR, B. (1994) Jamais fomos modernos. Rio de Janeiro: Editora 34.

. (1999) Políticas da natureza. Bauru: Editora da Universidade do sagrado Coração, 1999.

LUCARDIE, Paul (1999). Comment qualifier et répertorier les partis Verts? In: DELWIT, Pascal; DE WAELE, Jean-Michel. Les Partis Verts en Europe. Bruxelles: Editions Complexe, p.63-70.

LUCARDIE, Paul; RIHOUX, Benoît (2008). From amateur-activist to professional-electoral parties? On the organizational transformation of green parties in western democracies. In: FRANKLAND, E. Gene; LUCARDIE, Paul; RIHOUX, Benoît (Org.) Green parties in transition: the end of grass-roots democracy? London: Ashgate Publishing, 2008, p.3-18.

LUCARDIE, Paul (2018) . Zur Typologie der politischen Parteien. In: DECKER, F.; NEU V. (Orgs.) Handbuch der deutschen Parteien. Wiesbaden, p. 41-56. 
LIMONGI, Fernando; CORTEZ, Rafael. (2010), "As eleições de 2010 e o quadro partidário". Novos Estudos Cebrap, 88: 21-37.

MAINWARING, Scott. P. (2001) Sistemas Partidários em Novas Democracias: O Caso do Brasil. Rio de Janeiro. FVG

MAIR, Peter. (2008) The challenge to party government. West European Politics, v. 31, n. $1-2$, p. $211-234$

MALDONADO, Manuel Arias (2006). Izquierda verde y democracia deliberativa. In: SAIZ, Ángel Valencia (Org.). La izquierda verde. Barcelona: Icaria Editorial, p. 113-145.

MANIN, Bernard (1995) As metamorfoses do governo representativo. Revista Brasileira de Ciências Sociais, vol.10, n.29, p.5-34.

MANIN, Bernard (2013) A democracia do público reconsiderada. Novos Estudos CEBRAP. São Paulo, n.97, pp. 115-127.

MARENCO, André; SERNA, Miguel (2007). Por que carreiras políticas na esquerda e na direita não são iguais? Recrutamento legislativo em Brasil, Chile e Uruguai. Revista Brasileira de Ciências Sociais 22, no. 64: 93-113.

MARTÍNEZ, Waldo Barrera (2015). El ecologismo como corriente política contemporânea. Revista Caribeña de Ciencias Sociales, n. 12, p. 2-11.

MENEGUELLO, Rachel. (2000) Partidos Conservadores no Brasil. São Paulo. Paz e Terra.

MENEGUELLO, Rachel; BIZZARRO NETO, Fernando (2012). Contexto e Competição na Política Paulista. Dados, v.55, n.1, p.119-171

MIGNOLO, Walter D. (2008) Novas reflexões sobre a "idéia da América Latina": a direita, a esquerda e a opção descolonial. Caderno CRH, 21, no. 53 (2008).

MORIN, E. (1994) Introducción al pensamento complejo. Barcelona: Gedisa.

NICOLET, Sarah; SCIARINI, Pascal (2010). Le destin électoral de la gauche: le vote socialiste et vert en Suisse. Genéve: Georg Editeur.

OLIVEIRA, Wilson J. F. (2008) Gênese e redefinições do militantismo ambientalista no Brasil. Dados, vol.51, n.3, p. 751-777.

OLIVEIRA, Samir (2012) Ligado a evangélicos, Partido Ecológico Nacional cresce no Norte e no Nordeste. Rede Brasil Atual, 20/07/2012. Disponível em: http: / www.redebrasilatual.com.br/politica / 2012/07/ligado-a-evangelicos-partido-ecologico-nacional-cresce-no-norte-e-no-nordeste Consultado em 03/09/15.

PÁDUA, José Augusto (1986). Natureza e projeto nacional. Rio de Janeiro: IUPERJ.

PANEBIANCO, Angelo (1990). Modelos de partido. Madrid: Alianza Editorial.

PEREIRA, Frederico Batista (2014). A estabilidade e a efetividade da preferência partidária no Brasil. Revista Brasileira de Ciência Política, n.13, p. 213-244, 2014.

PERISSINOTTO, Renato M.; BRAUNERT, Mariana B. (2006) A direita, a esquerda e a democracia: os valores políticos dos parlamentares paranaenses (1995-2002). Opinião Pública 12, no. 1: 114-135.

PINHO, Isabel; RODRIGUES, Eleonora; SOUZA, Francislê; LOPES, Gaspar. (2014) Determinantes na Adoção e Recomendação de Software de Investigação Qualitativa: Estudo Exploratório. Internet Latent Corpus Journal, v. 4, n. 2, p.91-102.

DADOS - Revista de Ciências Sociais, Rio de Janeiro, vol. 61, n² 2, 2018 


\section{Antonio Teixeira de Barros}

RIECHMANN, Jorge (2006). La crítica socialista al capitalismo. In: SAIZ, Ángel Valencia (Org.). La izquierda verde. Barcelona: Icaria Editorial, p. 67-111.

RIBEIRO, Gustavo Lins (2000). Ambientalismo e desenvolvimento sustentado, In: RIBEIRO, G. L. Cultura e política no mundo contemporâneo. Brasília: EdUnB, p.130-170.

RIBEIRO, Pedro F. (2013) Organização e poder nos partidos brasileiros: uma análise dos estatutos. Revista Brasileira de Ciência Política, n.10, p. 225-265.

SACHS, I. (1993) Estratégias de transição para o século XXI: desenvolvimento e meio ambiente. São Paulo: Nobel.

SÁIZ, Ángel Valencia (2000). Teoría política verde: balance de una disciplina emergente. Revista Española de Ciencia Política 3: 181-194.

SÁIZ Ángel Valencia (2005). La izquierda verde: Aproximación a un modelo de izquierda radical en las sociedades democráticas. Anais do VII Congreso Español de Ciencia Política y de la Administración: Democracia y Buen Gobierno. Madrid, 21- 23 de septiembre de 2005.

SÁIZ, Ángel Valencia, A (2014). Política y Medio Ambiente. Cidade do México: Editorial Porrúa.

SAINTENY, Guillaume (1994). Le Parti socialiste face à l'écologisme. De l'exclusion d'un enjeu aux tentatives de subordination d'un intrus. Revue Française de Science Politique. Paris, v.44, n.3, p. 424-461.

SANDES-FREITAS, Vítor Eduardo (2015). Alianças partidárias nos estados brasileiros: das coligações às coalizões de governo (1986-2010). Tese de doutorado em ciência política, Campinas, IFCH, Unicamp.

SANTOS, Boaventura S. (2010) Pela mão de Alice. São Paulo: Cortez.

SANTOS, Adriana Vitória (2008). A institucionalização do movimento ambientalista: um estudo da formação do Partido Verde no Brasil. Dissertação Mestrado em Ciências Sociais, Pontifícia Universidade Católica de São Paulo, São Paulo.

SCAGLIOLA, Andrés (2002). Crisis de los partidos y crisis ambiental. Montevideo: Centro Latino Americano de Ecología Social.

SCHEEFFER, Fernando (2018). A alocação dos partidos no espectro ideológico a partir da atuação parlamentar. Revista E-Legis, v.11, n.27, sem paginação, 2018.

TAROUCO, Gabriela da Silva; MADEIRA, Rafael Machado (2013). Partidos, programas e o debate sobre esquerda e direita no Brasil. Revista de Sociologia e Política. Curitiba, v. 21, n. 45, p. $149-165$.

URBINATI, N. (2013) Crise e metamorfoses da democracia. Revista Brasileira de Ciências Sociais, São Paulo, v.28, n. 82, p.5-16.

VEIGA, L. F. (2007) Os partidos brasileiros na perspectiva dos eleitores. Opinião Pública, Campinas, v.13, n.2, p.340-365.

VIEIRA, Bergson Morais (2016). O movimento ambientalista frente às reconfigurações políticas e sociais no Brasil (1985-2002). Estudos de Sociologia, v. 21, n. 40, p. 117-135.

VIOLA, Eduardo J. (1987) O movimento ecológico no Brasil, 1974-1986: do ambientalismo à ecopolítica. Revista Brasileira de Ciências Sociais, v.1, n.3, sem paginação. 
WEBER, M. (1999) Economia e Sociedade. Brasília: Editora da UnB.

\section{Programas Partidários:}

Partido do Movimento Democrático Brasileiro. Programa partidário: http://pmdb.org.br/institucional/programa-partidario/ Consultado em $10 / 08 / 16$.

Partido Trabalhista Brasileiro: http://www.ptb.org.br/?page=ConteudoPage\&cod $=325$

Partido Socialista Brasileiro. Programa partidário: http://www.psb40.org.br/imprensa/programa.pdf Consultado em 11/08/14.

Partido dos Trabalhadores. Diretrizes partidárias: https://www.pt.org.br/wp-content/ uploads / 2014/05/DIRETRIZES-PROGRAMA-DE-GOVERNODILMA-PRESIDENTE-20141.pdf

Consultado em 12/08/16.

Democratas. Princípios do Democratas: http://www.dem.org.br/wp-content/uploads/2011/01/Principios-do-Democratas.pdf Consultado em 13/08/16.

Partido Republicano Brasileiro. Programa partidário: http:/ / www.prb10.org.br/o-partido-republicado-brasileiro/programa/ Consultado em 14/08/16.

Partido Comunista do Brasil. Programa Socialista para o Brasil:

http://www.pcdob.org.br/documento.php?id_documento_arquivo=1 Consultado em $15 / 08 / 16$.

Partido Comunista Brasileiro. A formação histórica do capitalismo: http:/ / www.pcb.org.br/portal/docs/historia1.pdf Consultado em 16/08/16.

Partido Democrático Trabalhista. Compromissos prioritários: http:/ / www.pdt.org.br/index.php/pdt/programa/1-compromissos-prioritarios Consultado em 17/08/16.

Partido Socialismo e Liberdade. Programa partidário. Disponível em: http://www.psol50.org.br/site/paginas/2 / programa Consultado em 18/08/16.

Partido da Causa Operária. Programa partidário: http:/ / www.pco.org.br/pco/programa.htm

Consultado em 19/08/16.

Partido dos Trabalhadores. Programa Partidário. 2016. Disponível em: h t t p s : / / w w w . p t. o r g. b r / w p - c o n t e n t / u p l oads /2014/05/DIRETRIZES-PROGRAMA-DE-GOVERNO-DILMA-PRESIDENTE20141.pdf Consultado em 17/08/16.

Partido Socialista dos Trabalhadores Unificado. Combater a destruição ambiental é lutar contra o capitalismo: http://www.pstu.org.br/node/20868 Consultado em $20 / 08 / 16$

Partido Progressista. Programa partidário: http://www.pp.org.br/textos /453/27435/ProgramaPartidario/?slT=119032 Consultado em 21/08/16.

DADOS - Revista de Ciências Sociais, Rio de Janeiro, vol. 61, n² 2, 2018 


\section{Antonio Teixeira de Barros}

Partido Popular Socialista. Documentos: http://www2.pps.org.br/2005/index.asp?portal=\&id_municipio=\&opcao $=$ documentos\&id_categoria $=3 \&$ flag $=\mathrm{s}$

Consultado em 22/08/16.

Partido Social Democrata Cristão. Programa partidário: http://www.psdc.org.br/sobre-nos/programa / Consultado em 23/08/16.

Partido Social Democrático. Princípios e valores: http://www.psd.org.br/principios-e-valores /

Disponível em: http:/ /pv.org.br/opartido/programa / Consultado em 24/08/16.

Partido Ecológico Nacional. Os 10 mandamentos para um crescimento sustentável: http:/ / www.pen51.org.br/mandamentos.php\#.U71Oc_ldWLE Consultado em $25 / 08 / 16$.

Partido Solidariedade: http://www.solidariedade77.org.br/secretarias/negro-indio-meio-ambiente-e-minorias / Consultado em 26/08/16.

Partido Socialista dos Trabalhadores Unificado. Combater a destruição ambiental élutar contra o capitalismo: http://www.pstu.org.br/node/20868 Consultado em $27 / 08 / 16$.

Partido Verde. Programa partidário: http://pv.org.br/opartido/programa/ Consultado em 30/08/14.

Rede Sustentabilidade. Programa partidário:

https:/ / s3-sa-east-1.amazonaws.com/rs-arquivos-uteis/Forma\%C3\%A7\%C3\%A3o/ valores-e-competencias+formatado.pdf Acesso em 12/12/16 
RESUMO

A Esquerda Verde: Partidos Políticos e Ambientalismo Radical no Brasil

O artigo analisa o perfil e as propostas dos partidos políticos brasileiros que defendem o ambientalismo radical ou ecossocialismo. Os programas dos 35 partidos registrados na Justiça Eleitoral foram analizados a fim de identificar o perfil ecológico de cada um. A partir dessa análise global, foram identificados oito partidos que se enquadram na categoria de ecossocialismo, cuja característica em comum é a crítica ao capitalismo e ao ambientalismo liberal. O referencial teórico reúne contribuições da sociologia dos partidos políticos e da sociologia ambiental. As conclusões mostram dois perfis de partidos ecossocialistas: os radicais e contrários ao sistema industrial capitalista; e os moderados, identificados como ecologistas sistêmicos (dois partidos). No primeiro caso estão seis legendas: PCdoB, PDT, PSOL, PCO, PSTU e PCB. No segundo grupo estão: PV e PEN. Para todos eles, entretanto, o Estado exerce um papel central como assegurador das políticas ambientais de caráter socialista.

Palavras-chave: Partidos políticos e ambiente; Ecossocialismo; Programas partidários; Esquerda verde.

\section{ABSTRACT}

The green left: political parties and radical environmentalism in Brazil

The article analyzes the profile and proposals of the Brazilian political parties that defend radical environmentalism or ecosocialism. The programs of the 35 parties registered in the Electoral Court were analized in order to identify the ecological profile of each one. From this global analysis, eight parties were identified as ecosocialists whose common characteristic is the critique of capitalism and liberal environmentalism. The theoretical framework brings together contributions from the sociology of political parties and environmental sociology. The conclusions show two profiles of ecosocialist parties: the radicals opposed to the capitalist industrial system; and the moderates, identified as systemic ecologists (two parties). In the first case there are six captions: PCdoB, PDT, PSOL, PCO, PSTU and PCB. In the second group are: PV and PEN. For all of them, however, the State plays a central role as the insurer of socialist environmental policies.

Keywords: Political parties and environment; Ecosocialism; Party programs; Green left. 
RESUMEN

La Izquierda Verde: Partidos Politicos y Ambientalismo Radical en Brasil

El artículo analiza el perfil y las propuestas de los partidos políticos brasileños que defienden el ambientalismo radical o el ecosocialismo. La metodología consistió en un análisis preliminar de los programas de los treinta e cinco partidos registrados en la Justicia Electoral, de modo a identificar el perfil ecologista de cada uno de ellos. A partir de esta análisis global, se identificaron ocho partidos que se encajaron en la categoría "ecosocialismo", cuya característica común es la crítica al capitalismo y al ambientalismo liberal. El referencial teórico del texto articula contribuciones de la sociología de los partidos políticos y de la sociología ambiental. Las conclusiones muestran dos perfiles distintos, entre los ecosocialista: los radicales y contrarios al sistema industrial capitalista (PCdoB, PDT, PSOL, PCO, PSTU y PCB); y los moderado, identificados como ecologistas sistémicos (PV y PEN). A pesar de esa diferencia, para todos ellos, el Estado ejerce un papel central como garante de las políticas ambientales de cuño socialista.

Palabras-clave: partidos políticos; ecologismo; ecosocialismo; programas partidarios; izquierda verde 